IZABELA KOCHAN

ORCID 0000-0002-0462-684X

Chrześcijańska Akademia Teologiczna

w Warszawie

\title{
NAUCZANIE ZDALNE \\ W OPINII UCZNIÓW SZKÓŁ ŚREDNICH W CZASIE TRWANIA PANDEMII COVID-19
}

AвSTRACt. Kochan Izabela, Nauczanie zdalne w opinii uczniów szkót średnich w czasie trwania pandemii COVID-19 [Distance Learning in the Secondary School Pupils' Opinion During the COVID-19 Pandemic]. Studia Edukacyjne nr 59, 2020, Poznań 2020, pp. 119-132. Adam Mickiewicz University Press. ISSN 1233-6688. DOI: 10.14746/se.2020.59.9

The Covid-19 pandemic triggered a general implementation of social distancing. According to UNESCO's data, schools have been closed in 165 countries. Pursuant to a decision of the Polish government of 12 March 2020, classes in educational establishments were suspended throughout Poland. The Internet, viewed from the beginning of its existence as a source of numerous threats and also of unprecedented access to information, became a tool enabling the continuity of educational activity. In the present reality, teachers facing social distance, confronted by challenges at work are also evaluated by students. The present article, based on empirical studies, contains secondary school students' opinions on the subject of the quality of distance learning. Critical opinions result explicitly from the fact that they are expressed by people having "digital attachment to modern technology" and possess their own equipment with unlimited network access. This unprecedented state of emergency emphasizes most teachers' unpreparedness for switching overnight to the online mode, which should not come as a surprise to anybody, because reliable preparation for distance classes involves not only the skill but also planning and proper preparation of teaching materials. Importantly, during online learning students begin to miss other people and interaction with their teachers, which emphasizes the importance of direct human relations, unduly underrated in "normal reality". Regardless of various opinions on the subject of distance learning, it is obvious that forced switching to online learning can and even be a catalyst of change in the educational field.

Key words: Covid-19, distance learning, students' opinions, modern technologies

\section{Wprowadzenie}

Większość rządów na całym świecie w obawie przed rozprzestrzenianiem się pandemii COVID-19 tymczasowo zamknęła instytucje edukacyjne ${ }^{1}$. W mar-

${ }^{1}$ Przeprowadzone badania oparte na przeglądzie danych elektronicznych wskazują na zasadność takiego postępowania, jednak brakuje jednoznacznych dowodów na to, by środki 
cu 2020 roku dyrektorzy polskich szkół z dnia na dzień zostali zmuszeni do przejścia z prowadzenia szkoły stacjonarnej do jej wirtualnego odpowiednika. Pandemia całkowicie przebudowała naszą przestrzeń życiową. Zmiany w obszarze edukacji zachodzące w głębokim kryzysie obnażyły nierówności nie tylko w zakresie jakości sprzętu informatycznego, jakim dysponujemy, czy też przepustowości łącza internetowego, ale przede wszystkim pokazały, na ile wykształcone zostały umiejętności samokształcenia, tak bardzo potrzebne w dobie, kiedy znacząca część działań w zakresie edukacji zależy od samych uczniów. Obecna sytuacja zwraca uwagę także na znaczenie szkoły nie tylko jako miejsca rozwoju intelektualnego, ale również, albo przede wszystkim, wspólnej przestrzeni.

Nowoczesne technologie dostarczają wielu narzędzi umożliwiających zarówno przekaz treści, jak i rozszerzanie zapośredniczonych relacji międzyludzkich, także w obrębie społeczności szkolnej. Niewątpliwie jednak sytuacja, w której rzesza nauczycieli została zmuszona do wdrożenia nauczania online, bez odpowiedniego przygotowania, treningu, często z ograniczeniami sprzętowymi, wpływa na ocenę ich pracy. Wystarczy przeczytać kilka artykułów prasowych lub komentarzy internautów o nauczaniu zdalnym, by mieć duże wątpliwości co do skuteczności wprowadzonego w Polsce na czas pandemii nauczania online. Kształtowanie opinii publicznej na temat pracy dydaktycznej oparte na słowach: Od trzech dni tłumacze mojej 60-letniej mamie, czym jest Messenger, jak wysłać zbiorowego maila i jak założyć grupę na Facebooku², wypowiadane przez córkę nauczycielki, uwydatniają skalę problemu.

Nauczanie postrzegane jako swoista misja jest szczególnie trudne do realizacji w czasach, kiedy wszystkie kontakty z realnych muszą przenieść się na płaszczyznę przestrzeni wirtualnej. Kontakty zapośredniczone, będące domeną współczesnej młodzieży nagle stały się obligatoryjne dla wszystkich nauczycieli różnych szczebli edukacji, niezależnie od wieku i poziomu kompetencji cyfrowych. Przeniesienie uczniów z całej Polski na płaszczyznę nauki online wyraźnie uwidoczniło nierówności w systemie edukacji, poczynając od dzieci, które w tej sytuacji pozostały bez posiłku, bez urządzeńn ${ }^{3}$ nielimito-

kontroli społecznej w postaci zamknięcia szkół były skutecznym środkiem zabezpieczającym przed rozprzestrzenianiem się wirusa. Szerzej w: R.M. Viner i in., School closure and management practices during coronavirus outbreaks including COVID-19: a rapid systematic review, Lancet Child Adolesc Health, 2020, 4, s. 397-404.

${ }^{2}$ Córka nauczycielki: to nie jest szkoła XXI w., a jedna wielka mistyfikacja https://kobieta. onet.pl/corka-nauczycielki-to-nie-jest-szkola-xxi-wieku-a-jedna-wielka-mistyfikacja/tsj057c, [dostęp: 30.04.2020].

${ }^{3}$ E-lekcje trwają, jednak część dzieci pozostaje wykluczona cyfrowo. Istniejące nierówności cyfrowe zostały znacząco zaostrzone przez pandemię COVID-19. O niedoborach $\mathrm{w}$ zakresie wyposażenia szkół świadczy zainteresowanie programem „zdalna szkoła”, w ramach którego od 1 kwietnia 2020 r. można pozyskać środki na zakup laptopów lub komputerów dla uczniów i nauczycieli - w ramach Programu Operacyjnego „Polska Cyfrowa”. Szerzej na temat 
wanego dostępu do Internetu, kończąc na tych, których sprzęt i kompetencje w zakresie obsługi nowoczesnych technologii znacząco wyprzedzają możliwości i umiejętności pozostałych uczestników procesu edukacji.

Pozostaje również kwestia, czy uczniowie mogą korzystać z pomocy rodziców, czy rodzice posiadają odpowiednie kompetencje cyfrowe, czy mają czas i możliwości, czy nie pracują na przykład na „pierwszej linii frontu”, co wiąże się z dodatkowym ogromnym obciążeniem psychicznym rzutującym na funkcjonowanie całej rodziny ${ }^{4}$. Niewątpliwie jednak, w zaistniałej sytuacji w wielu wypadkach to młodzież jest lepiej przygotowana do korzystania z nowoczesnych technologii niż dorośli.

Niniejszy tekst jest efektem próby odpowiedzi na pytanie o ocenę jakości kształcenia zdalnego w opinii uczniów szkół średnich. Badania wskazują bowiem, że młodzież nabywająca umiejętności cyfrowe już we wczesnym dzieciństwie ma ułatwione zadanie w dziedzinie ich wykorzystania w edukacji szkolnej ${ }^{5}$. Są one podstawą do postawienia hipotezy, że uczniowie szkół średnich negatywnie oceniają działania nauczycieli w okresie zawieszenia zajęć bezpośrednich w placówkach szkolnych.

\section{Materiały i metody}

W niniejszym badaniu zastosowano metodę sondażu diagnostycznego. Badanie przeprowadzono z wykorzystaniem formularza Google od 14 do 30 kwietnia 2020 roku. W sondażu wzięło udział 114 osób. Ankiety były przeprowadzane w sposób anonimowy, toteż wypowiedzi przytaczane w tekście również są anonimowe. Badanie dokonane na tak małej próbie, uwzględniając

szczegółów w: http://cyfrowaszkola.eu/home/laptopy-dla-szkol, [dostęp: 30.04.2020]. 90\% samorządów, jako organy prowadzące szkoły, zgłosiło już wnioski o dofinansowanie J. Ptak, Duże zainteresowanie programem "Zdalna szkota". 90 proc. samorząów ubiega się o dofinansowanie, https:/ / poznan.tvp.pl/47649739/duze-zainteresowanie-programem-zdalna-szkola-90-procsamorzadow-ubiega-sie-o-dofinansowanie, [dostęp: 30.04.2020]; Nierówności w dostępie do nowoczesnych technologii w czasie pandemii są formą nierówności społecznych, które mają ogromny wpływ na szeroko pojęte zdrowie. Ograniczony dostęp do nowoczesnych technologii z nieograniczonym dostępem do Sieci jest równoznaczny z ograniczeniem w dostępie do usług, zasobów informacyjnych, utrzymywania kontaktów społecznych. Szerzej na ten temat w: E. Beaunoyer'S. Dupéré, M.J.Guitton, COVID-19 and digital inequalities: Reciprocal impacts and mitigation strategies, Computers in Human Behavior, 2020, 111, s. 1-9.

${ }_{4}^{4}$ Życie w trakcie pandemii COVID-19 wiąże się z dodatkowym stresem wyzwalanym przez zagrożenie utraty zatrudnienia, osób bliskich, niepewność finansową, izolację społeczną. Brak bezpośredniego dostępu do specjalistów z zakresu zdrowia psychicznego bądź jego ograniczenie może poszerzać krąg osób, u których następuje nasilenie stanów depresyjnych.

${ }^{5}$ L.B. Hurwitz, K.L. Schmitt, Can children benefit from early internet exposure? Short- and long-term links between internet use, digital skill, and academic performance, Computers \& Education, 2020, 146, s. 8 . 
ogólną liczbę uczniów szkół średnich w Polsce, nie daje prawa do budowania precyzyjnych zestawień statystycznych, wskazania liczbowe dokumentują jedynie pewne tendencje $\mathrm{w}$ ocenie działalności nauczycieli w przestrzeni wirtualnej.

Wśród respondentów 59,6\% stanowiły kobiety. Zdecydowana większość (96,5\%) to uczniowie szkół średnich, którzy są absolwentami gimnazjów, z czego 80,7\% stanowią uczniowie liceów ogólnokształcących. W tej grupie $50,9 \%$ to uczniowie klas maturalnych. Zwraca uwagę fakt, że $77,7 \%$ osób kształcących się w technikach to kobiety. W skład próby badawczej wchodzili uczniowie zamieszkujący zróżnicowane środowiska, z przewagą osób zamieszkujących miasta ${ }^{6}$.

\section{Wyniki badania}

$\mathrm{Na}$ początku respondenci zostali poproszeni o wskazanie narzędzi wykorzystywanych przez nauczycieli $\mathrm{w}$ pracy online, $\mathrm{z}$ uszczegółowieniem częstotliwości ich wykorzystania. Z analizy uzyskanych danych wynika jednoznacznie, że najczęstszym nośnikiem komunikacji $\mathrm{w}$ odniesieniu do badanej grupy jest dziennik elektroniczny ${ }^{7}$. Wykorzystanie tego narzędzia wydaje się oczywiste, zwłaszcza w kontekście tego, że od roku 2009 szkoły mają możliwość rezygnacji z dokumentacji papierowej oraz korzystania wyłącznie z dzienników elektronicznych i wiele z nich wdrożyło właśnie tę for$\mathrm{mę}^{8}$. Kolejnymi, najczęściej wykorzystywanymi narzędziami przekazu wiedzy są, zgodnie ze wskazaniem respondentów, poczta elektroniczna, Teams, Messenger. Żaden z uczniów nie miał do czynienia z tablicą Linoit, portalem Scholaris.pl. Ta sama sytuacja miała miejsce $\mathrm{w}$ odniesieniu do portalu LearningApps, który jest narzędziem umożliwiającym tworzenie interaktywnych gier edukacyjnych'. Portal LearningApps jest bezpłatny i od wielu lat ma polską wersję językową, co pozwala również zaangażować młodzież w tworzenie gier zgodnych z tematyką prowadzonych lekcji. Badania dowodzą, iż pokolenie $Y$ nauczanie tradycyjne postrzega jako nudne i nieskuteczne, nato-

${ }^{6}$ Wieś: 42,1\%, małe miasto, do 100 tys. mieszkańców: 43,9\%, duże miasto, powyżej 100 tys. mieszkańców: $14 \%$.

7 Wskazania bardzo częstego wykorzystywania danego narzędzia dotyczą kolejno: dziennika elektronicznego (52,63\%), poczty elektronicznej (15,79\%), Microsoft Teams (15,79\%), Mesengera ((14,03\%), Zooma (8,77\%), dysku Google (5,26\%), platformy Moodle (3,5\%).

${ }^{8}$ Rozporządzenie Ministra Edukacji Narodowej z 16 lipca 2009 r. zmieniające rozporządzenie w sprawie sposobu prowadzenia przez publiczne przedszkola, szkoły i placówki dokumentacji przebiegu nauczania, działalności wychowawczej i opiekuńczej oraz rodzajów tej dokumentacji (DzU 2009, nr 116, poz. 977).

${ }^{9}$ Dodatkową funkcjonalnością portalu jest możliwość utworzenia wirtualnej klasy. 
miast jako rozwijające wskazują zajęcia interaktywne. Grywalizacja wspiera umiejętności i znacząco wpływa na przyswajanie wiedzy. Istnieje powiązanie pomiędzy włączaniem elementów gry do nauczania a poziomem utrwalenia wiedzy ${ }^{10}$, co świadczy o przydatności włączania zasad grywalizacji do działań edukacyjnych ${ }^{11}$.

Przedłużający się stan przeniesienia zajęć na płaszczyznę online wymusił również na nauczycielach ocenę pracy zdalnej uczniów. Od 25 marca 2020 roku, zgodnie z rozporządzeniem Ministra Edukacji Narodowej ${ }^{12}$, nauczyciele mogą wystawiać oceny. Wobec powyższego poproszono respondentów o udzielenie odpowiedzi na pytanie: czy mieli do czynienia z jakąkolwiek formą sprawdzenia nabytej wiedzy, która została oceniona. 61,4\% ankietowanych wskazało, że miało do czynienia ze sprawdzeniem wiedzy za pośrednictwem Internetu ${ }^{13}$. W kategorii inne $(8,8 \%)$ zwracają uwagę następujące wypowiedzi: prace do wykonania na krótkie terminy z absurdalnym systemem oceniania; wyłacznie prace domowe na oceny; jedni prowadza inni wbrew logice mówia, że trzeba było zdobywać oceny w szkole i będzie taka możliwość, jak tylko do niej wrócimy, jak pytamy w klasie co będzie jak nie wrócimy, to nie uzyskujemy odpowiedzi. Ankietowani, którzy na powyższe pytanie odpowiedzieli twierdząco byli zobowiązani do wskazania przedmiotu oraz narzędzia wykorzystanego przez nauczyciela.

Spośród wymienionych przedmiotów dominował język angielski, dodatkowo wymieniano język polski, matematykę, fizykę, edukację dla bezpieczeństwa oraz geografię. Najczęściej wykorzystywano pocztę internetową, za jej pośrednictwem wysyłano zdjęcia wykonanej pracy, która w przypadku sprawdzianów miała jasno określone ramy czasowe. Zwraca jednak uwage wykorzystanie narzędzi nie wymienionych w pytaniu pierwszym ankiety: Microsoft Forms, testportal, discord, testportal, quizlet, quizziz, co świadczy o tym, że nauczyciele starają się usprawnić swoje działania w ramach nauczania zdalnego. Niestety, takie działania są także obarczone ryzykiem, o czym świadczy następująca wypowiedź: to był cyrk, dostaliśmy sprawdzian przygotowany w formularzu Google, zamiast sprawdzianu do wypetnienia dostaliśmy gotow-

10 Szerzej na ten temat w: L.M. Putz, F. Hofbauer, H. Treiblmaier, Can gamification help to improve education? Findings from a longitudinal study, Computers in Human Behavior, 2020, 110, s. 1-12.

11 Tamże.

12 Rozporządzenia Ministra Edukacji Narodowej z 25 marca 2020 r. zmieniające rozporzadzenie w sprawie szczególnych rozwiąań w okresie czasowego ograniczenia funkcjonowania jednostek systemu oświaty w związu z zapobieganiem, przeciwdziałaniem i zwalczaniem COVID-19 (DzU poz. 530).

13 Należy podkreślić, że ankieta została zamknięta 30 kwietnia. Uwzględniając fakt dalszego zawieszenia zajęć szkolnych, można domniemywać, że odsetek nauczycieli oceniających proces nabywania wiedzy w formie zdalnej będzie stale wzrastał. 
ca z właściwymi odpowiedziami, oczywiście wszyscy natychmiast zrobili prtscn żeby mieć później z czego korzystać, to beznadziejne i świadczy o tym, że nauczyciele nie maja pojęcia o możliwościach online $e^{14}$.

Uczniowie zwracają również uwagę na łatwość zdobywania pozytywnych not w procesie kształcenia zdalnego. 71,9\% stwierdziło, że oceny w nauczaniu online łatwiej zdobyć, a 5,3\% że trudniej je zdobyć, natomiast 19,3\% wyraziło opinię o braku różnicy w ocenianiu. W kategorii inne (3,5\%) znalazły się między innymi następujące wypowiedzi ilustrujące, na czym polega wskazywana przez większość uczniów łatwość uzyskiwania pozytywnych ocen: zupetnie nie ma porównania, sprawdzian pisany przez dwa dni, bo taki termin wskazat nauczyciel to nie sprawdzian; teraz uzyskanie dobrej oceny to pryszcz, nauczyciele nie maja przeciez kontroli nad tym co robimy np. w czasie sprawdzianu, zazwyczaj rozwiąujemy go w grupie klasowej na jakimś komunikatorze, wykorzystujemy znajomości z kujonami, dostęp do portali, w których po zapłaceniu kilku złotych ma się dostęp do większości odpowiedzi.

W kolejnej części ankiety uczniowie zostali poproszeni o wyrażenie swojej opinii na temat nauczania zdalnego. Analizując wypowiedzi respondentów wymieniających pozytywy związane z wprowadzeniem nauczania zdalnego, można jednoznacznie stwierdzić, iż mają one niewiele wspólnego z edukacją. Najczęściej wskazywano na możliwość wyspania się; większą swobodę, czas dla siebie; zaoszczędzony czas, poświęcany dotychczas na dojazdy do szkoły; możliwość uczestnictwa w lekcjach nawet w tóżku. Wypowiedzi nawiązujące do edukacji najczęściej dotyczyły łatwości zdobywania ocen oraz możliwości poświęcenia czasu na przygotowanie się do matury. Wśród negatywnych opinii dotyczących kształcenia online dominują wypowiedzi zwracające uwagę na znaczne przeciążenie uczniów ilością przekazywanego do realizacji materiału: narzucanie na uczniów ilości zadań niemożliwych do opracowania przy czym nauczyciel nic nie tłumaczy tylko każe robić zadania; dtugi czas przed komputerem; mato umiem z lekcji on-line, to nie jest prawdziwe online tylko pośredni kontakt z nauczycielem; nauczyciele narzucaja większy materiat do opracowania w domu niż ten który realizowali w szkole; uczeń jest pozostawiony sam sobie, samodzielnie musi przerabiać tematy, które byłyby omówione na lekcji; nauczyciele wysyłaja bardzo dużo obszernych prac domowych po samodzielnej realizacji tematu i ciężka jest realizacja wszystkiego w terminie; uczeń zostaje zasypany zadaniami, których normalnie na lekcjach nie wykonuje. Przytoczone wypowiedzi pozwalają wysnuć wniosek, że zaburzona została równowaga pomiędzy działaniami nauczycieli i uczniów w odniesieniu do sytuacji, z jaką respondenci mieli do czynienia podczas pobierania edukacji w szkole. Wiele negatywnych opinii

${ }^{14}$ 61,40\% respondentów wymieniło przedmioty, w ramach których nauczyciel prowadzący przeprowadził sprawdzian wiedzy, z czego 77,14\% wskazało na narzędzia, za pośrednictwem których ten sprawdzian przeprowadzono. 
na temat kształcenia zdalnego dotyczyło utraty bezpośrednich kontaktów interpersonalnych, zarówno z nauczycielem jak i z rówieśnikami. Taki stan rzeczy dowodzi, że młodzi ludzie przywiązują dużą wartość do osobistego kontaktu z nauczycielem, jak też innymi uczniami. Zwracano również uwagę na kwestie techniczne dotyczące sprzętu, to jest na problemy z łączem internetowym i ogólna dostępnościa mediów. W odniesieniu do tej kwestii należy podkreślić, że badania jednoznacznie dowodzą, iż jakość audio i wideo jest kluczowym czynnikiem udanego zdalnego uczenia się ${ }^{15}$.

Zwracając uwagę na wypowiedzi respondentów oraz wskazania wykorzystywanych narzędzi, można stwierdzić, że prowadzone nauczanie zdalne nie jest równoznaczne z komunikacją między uczestnikami procesu dydaktycznego w czasie rzeczywistym. Tymczasem, jak dowodzą Kucuk i Richardson, dobrze zaprojektowany interfejs do nauki online znacząco wpływa na emocjonalne zaangażowanie uczniów w naukę oraz zwiększa ich zadowolenie $^{16}$. Ponadto, wdrożenie narzędzi online w celu zrekompensowania utraty interakcji twarzą w twarz w tradycyjnym otoczeniu edukacyjnym może również zwiększyć motywację poszczególnych uczniów do nauki ${ }^{17}$. Wobec powyższego, należałoby podjać́ działania mające na celu podniesienie kompetencji cyfrowych nauczycieli tak, aby w sytuacji konieczności rozpoczęcia kolejnego roku szkolnego w trybie zdalnym dążyć do realizacji lekcji w sposób, w jakim nauczyciele będą mieli większą kontrolę nad przebiegiem procesu kształcenia. Jest to o tyle zasadne, że ogólna ocena przygotowania nauczycieli do nauczania zdalnego nie jest najlepsza. Zaledwie 3,5\% respondentów oceniło je jako bardzo dobre. Dominowały oceny dostateczne (40,4\%). W kategorii „inne” zwracają uwage następujące wypowiedzi: dają więcej materiału do opracowania niż sami kiedykolwiek robili na lekcji; nauczyciele nie maja szans być dobrze przygotowani; zaczynając od tego, że nie każdy z nauczycieli ma pomyst na prowadzenie lekcji za pomoca dostępnych platform, przez brak umiejętności i konieczność nabywania ich podczas lekcji z uczniami, kończąc na braku możliwości sprzętowych; niestety, jeżeli połowa 45-minutowej lekcji polega na uczeniu nauczyciela, co właściwie ma robić, aby było go stychać lub jak ma używać tablicy, to chyba mija się to z celem, zwłaszcza dla roczników które przerobity już materiał i zaraz miały pisać końcowe egzaminy; niektórzy nauczyciele wykazuja naprawdę ogromne chęci do pracy w zaistniałych warunkach, ale zwyczajnie nie sa w stanie; nikt nie jest przygotowany do tej sytuacji; to w znacznej mierze zależy od konkretnego nauczyciela. Wy-

15 A. Raes i in., Learning and instruction in the hybrid virtual classroom: An investigation of students' engagement and the effect of quizzes, Computers \& Education, 2020, 143, s. 14.

16 S. Kucuk, J.C. Richardson, A structural equation model of predictors of online learners' engagement and satisfaction, Online Learning, 2019, 23(2), s. 196-216.

17 J-N. Sun, Y-C. Hsu, Effect of interactivity on learner perceptions in web-based instruction, Computers in Human Behavior, 2013, 29(1), s. 171-184. 
powiedzi respondentów pozwalają jednoznacznie stwierdzić, iż wymogiem współczesności w procesie kształcenia nauczycieli jest przygotowanie ich do pracy zdalnej. Uwzględniając obecne warunki, w jakich funkcjonuje społeczność szkolna, należałoby rozważyć możliwość wdrożenia na stałe nauczania hybrydowego. Nauczania wymagającego połącznia przestrzeni off i online, które w sytuacji zagrożenia zostanie płynnie przeniesione w przestrzeń wirtualną.

Respondenci zostali poproszeni również o wskazanie przedmiotów, których treści $\mathrm{w}$ ich ocenie są najgorsze oraz najlepsze do realizacji $\mathrm{w}$ formie zdalnej. Wśród przedmiotów najgorszych wskazywano najczęściej przedmioty ścisłe, uzasadniając to brakiem rozumienia treści. Niemniej jednak należy podkreślić, iż w przypadku trudności z wykonaniem zleconego zadania $17,5 \%$ ankietowanych może zawsze liczyć na pomoc nauczyciela, a 45,6\% często. Dodatkowo, wśród przedmiotów trudnych do realizacji w formie zdalnej wskazano zajęcia wychowania fizycznego, co było bezpośrednio powiązane z zaangażowaniem nauczycieli $\mathrm{w}$ dbałość o kondycję fizyczną uczniów w czasie ograniczeń w przemieszczaniu się, co wyrażało się w zlecaniu określonych ćwiczeń do wykonania i przesłania nagrania swej aktywności, celem potwierdzenia jej wykonania. Jako najprostsze do przyswojenia za pośrednictwem narzędzi internetowych były wskazywane takie przedmioty, jak język polski czy historia, co było uzasadniane tym, że są to przedmioty wymagające głównie pamięciowego opanowania treści.

W kontekście uwag dotyczących trudności w rozumieniu treści niektórych przedmiotów respondenci zostali poproszeni o udzielenie odpowiedzi na pytanie: czy korzystają z korepetycji. 45,6\% respondentów twierdzi, iż z nich nie korzysta, ponieważ nie ma takiej potrzeby, 19,3\% korzysta z korepetycji online, $7 \%$ z korepetycji z bezpośrednim kontaktem z nauczycielem, a 28,1\% nie korzysta tylko dlatego, że nie ma takiej możliwości. Uczniowie mogą również liczyć na pomoc rodziców w edukacji szkolnej (54,38\%), których działania nie tylko w ocenie respondentów są bezpośrednio związane z nauką. Wśród działań pomocowych najczęstsze odpowiedzi dotyczą stworzenia odpowiednich warunków do nauki w postaci sprzętu, prywatnej przestrzeni i ciszy oraz odciążenia w postaci ograniczenia obowiązków domowych. Szczególną uwagę zwracają wypowiedzi dotyczące ograniczenia obowiązków domowych, co wskazuje, iż rodzice dostrzegają większe obciążenie zadaniami szkolnymi w trakcie nauczania zdalnego, niż miało to miejsce podczas zajęć realizowanych w szkole. Respondenci zwracali również uwagę na zapewnienie środków finansowych na korepetycje. Ankietowani jako formę pomocy udzielanej im przez rodziców wskazywali także wsparcie psychiczne (31\%). Analiza jakościowa wykazuje korelację pomiędzy okazywanym wsparciem psychicznym a wykształceniem wyższym i zawodowym rodziców oraz pra- 
cą wykonywaną w formie bezpośredniej. Wśród osób sygnalizujących brak pomocy $(45,62 \%)$ dominowały odpowiedzi wskazujące na brak takiej potrzeby i umiejętność podejmowania samodzielnych działań w celu pozyskiwania wiedzy $\mathrm{w}$ przypadku niezrozumienia materiału przedmiotowego. Ponadto, zwrócono uwagę na niższy poziom wiedzy rodziców, co tym samym uniemożliwia im taką pomoc.

Mimo generalnie złej oceny nauczania zdalnego uczniowie w większości nie postrzegają tego roku jako straconego (45,5\% nie, 19,3\% nie mam zdania). Podkreślają, że program nauczania jest nadal realizowany, w niektórych przypadkach nauki jest nawet więcej. Akcentowano, że chcący się uczyć zdobędą wiedzę bez względu na sytuację, chociaż stan pandemii rozleniwia i obniża produktywność. Wśród 19,3\% respondentów, uznających aktualny rok szkolny za stracony dominują opinie maturzystów, których zdanie ilustrują następujące wypowiedzi: jest to dla mnie rok stracony, gdyż jestem w maturalnej klasie, poza straconymi najdłuższymi wakacjami w życiu strace też szansę zrobienia zdjęcia przed szkoła ze świadectwem, pożegnania się z nauczycielami, kolegami; materiat do matury z niektórych przedmiotów nie został zrealizowany do końca przed rozpoczęciem zdalnego nauczania, więc realizowaliśmy go przez Internet, przez większość moich kolegów oraz mnie nie zostat dokładnie zrozumiany, co może odbić się na wynikach matury; mimo że to nie chodzi o caty rok, a dotyczy to tylko ostatniej części, jest to dla mnie jak i zapewne dla innych maturzystów najważniejszy okres w szkole $i$ dlatego caty rok jest dla mnie stracony; uważam ten rok za stracony, ponieważ ledwo zdążyliśmy przerobić materiat do matury, a tutaj pandemia, zdalne nauczanie nie jest najlepsza forma przygotowywania do matury, nie ma możliwości odpowiedniej powtórki niezbędnego materiału, choćby zadań z matematyki, ja osobiście uważam, że matury powinny zostać odwołane i powinny być wyłacznie egzaminy na studia, gdyż będzie można je odtożyć w czasie i taki kandydat będzie mógł bezpośrednio przygotowywać się do takiego egzaminu, stricte pod kontem swoich studiów, a nie będzie musiat się stresować maturami, które na chwilę obecna stanowia śmiertelne zagrożenie ${ }^{18}$. Stracony rok to również zaległości w realizacji przedmiotów zawodowych stanowiących integralną część edukacji w technikach. Z analizy jakościowej wynika, że osoby uważające ten rok za stracony wcale nie są zainteresowane jego przedłużeniem.

Respondenci zostali również zapytani, czego najbardziej im brakuje podczas zawieszenia zajęć w szkole. 3,5\% ankietowanych stwierdza, iż niczego im nie brakuje oraz że taka forma nauki im odpowiada, co uzasadniane jest: spokojem, brakiem stresu szkolnego, możliwością poświęcenia większej ilości czasu na własne zainteresowania. W opinii 95\% wybrzmiewa, że najbar-

${ }_{18}$ Poza maturzystami wypowiadali się również uczniowie młodszych klas, którzy uzasadniali swą opinię na temat straconego roku niską jakością nauczania zdalnego (27,27\% z grupy osób uznających rok szkolny za stracony). 
dziej dotkliwie odczuwają oni brak bezpośredniego kontaktu z drugim człowiekiem, rówieśnikami, nauczycielami. Biorąc pod uwagę fakt, że uczniowie przywiązują dużą wartość do osobistego kontaktu, wskazanie na braki w tym zakresie nie stanowią żadnego zaskoczenia. Wypowiedzi zawierają również treści wskazujące na obawy, że sytuacja konieczności zachowania dystansu społecznego może się znacząco przedłużyć $(17,54 \%)$, a w przypadku skrajnym może nawet towarzyszyć im do końca życia. Młodzież jest przygnębiona i sfrustrowana tą sytuacją, co wskazuje również na konieczność udzielenia im wparcia psychicznego. Jest to o tyle ważne, że obawa o zdrowie własne i bliskich, którzy znajdują są w grupie ryzyka jest udziałem $47 \%$ respondentów. Respondenci wyrażają również obawę o płynność finansową w gospodarstwie domowym, co jest skorelowane $\mathrm{z}$ tym, że ich rodzice zostali zmuszeni do zawieszenia działalności gospodarczej bądź zostali zwolnieni z pracy ze względu na znaczący spadek dochodów firmy zatrudniającej. Uczniowie obawiają się ograniczeń wprowadzonych $\mathrm{w}$ ramach przeciwdziałania rozprzestrzenianiu się wirusa $(7,01 \%)$, w tym bezwzględnego zakazu wyjścia; tego $\dot{z}$ e sytuacja będzie trwała dtu̇̇ej niż wszyscy zakładają ${ }^{19}$. 31,57\% respondentów odczuwa obawy związane z ostatecznymi rozwiązaniami dotyczącymi matury. Należy zwróć uwagę na fakt, iż część ankiet została wypełniona w czasie, gdy terminy matur nie były jeszcze znane. Obawy dotyczą także możliwości odwołania matur: boję się, że się nie odbędzie i zrobia konkurs świadectw, a wiadomo, że w jednej szkole można mieć 6, a w innej jest to ledwo 3; boje się perspektywy przesunięcia matur (na lipiec, sierpień) i przesunięcia roku akademickiego.

Przedłużająca się izolacja społeczna wpływa również na relacje rodzinne. $\mathrm{Z}$ jednej strony: kwarantanna jest akurat dobra na to, by pogłębiać relacje rodzinne; jest czas na rozmowy i docenienie siebie, z drugiej natomiast niektóre osoby $w$ rodzinie nie sa w stanie przebywać w miejscu przez dłuższy czas; wszyscy sa już soba trochę zmęczeni; zbyt częste interakcje między członkami rodziny oddziatuja negatywnie na relacje rodzinne sytuacja jest napięta; tata więcej pije $e^{20}$. Ostatnia wypowiedź potwierdza, że sytuacja wymuszonej izolacji spowodowanej rozprzestrzenianiem się pandemii stanowi zagrożenie dla części osób, które $\mathrm{w}$ tej rzeczywistości są pozbawione niezbędnego wsparcia ${ }^{21}$. Tylko niewielka

${ }^{19}$ Odpowiedzi związane z długością trwania pandemii oraz ograniczeniami z nią związanymi i zagrożeniem zdrowia najbliższych.

${ }^{20} \mathrm{~W}$ odpowiedzi na pytanie: W jaki sposób konieczność częstszego przebywania we wspólnym gronie wptywa na relacje rodzinne? 40,35\% respondentów odpowiedziało, że nic się nie zmieniło; $38,60 \%$ wskazało na pozytywne aspekty w postaci możliwości wspólnego spędzania czasu, częstszych rozmów, co skutkuje zacieśnianiem więzi rodzinnych; 21,05\% przebywanie we wspólnym gronie ocenia jako negatywne, związane z częstszymi kłótniami, które wyzwalają dodatkowe konflikty.

${ }^{21}$ To widoczny efekt kwarantanny $i$ dotyczy wszystkich krajów, w których wprowadzono element izolacji społecznej - mówi Izabela Żbikowska z Fundacji “HumanDoc”. I wylicza: wzrost przemocy 
grupa respondentów (10,52\%) nie dostrzega większych zmian w funkcjonowaniu rodziny, co jest skorelowane $\mathrm{z}$ brakiem zmian $\mathrm{w}$ formie wykonywanej dotychczas pracy rodziców.

W związku z wprowadzonymi ograniczeniami młodzież spędza czas wolny w domu. $43,85 \%$ opisując czynności wykonywane w czasie wolnym, wskazuje między innymi na naukę, co w zdecydowanej większości jest powiązane $\mathrm{z}$ tym, iż w tym roku przystąpią do matury. 54,38\% spędza czas na grach komputerowych, 29,82\% na czytaniu książek, 22,8\% na oglądaniu filmów, 3,5\% na słuchaniu muzyki, 3,5\% na ćwiczeniach fizycznych. Zwraca uwagę czas wolny spędzony na grach komputerowych. Oczywiście, niektóre gry wideo mogą promować naukę, rozwiązywanie problemów, mogą oddziaływać na rozwój umiejętności motorycznych i koordynacji, niemniej jednak gry najbardziej popularne wśród młodzieży dalekie są od takich treści, w pewnych przypadkach mogą nawet wywoływać problemy psychologiczne i behawioralne.

Badania online przeprowadzone na terenie Niemiec, Austrii i Szwajcarii, opisujące rzeczywistość szkolną z perspektywy różnych uczestników i współuczestników procesu dydaktycznego w czasie trwania pandemii ${ }^{22}$, potwierdzają wskazane $\mathrm{w}$ opisie badań własnych przeciążenie uczniów poprzez stawianie im nadmiernych wymagań, co jest dostrzegane również przez rodziców. Problem ten sygnalizowany jest częściej w odniesieniu do dzieci w młodszym wieku szkolnym, z uwagi na konieczność pogodzenia zaangażowania się $\mathrm{w}$ działania dziecka $\mathrm{z}$ aktywnością zawodową. Zwrócono również uwagę na braki w zasobach sprzętowych zarówno w szkołach, jak i gospodarstwach domowych. Około 10\% rodziców zwróciło uwagę na niedobory w tym zakresie, co potwierdzają wypowiedzi samych uczniów. Podkreślono, że samodzielność uczniów podczas nauki $\mathrm{w}$ domu promuje odpowiedzialne uczenie się. Kompetencje cyfrowe nauczycieli pracujących na terenie wyżej wymienionych państw są bardzo różnie oceniane. Sami nauczyciele akceptują pracę w formie zdalnej, którą postrzegają jako właściwą w odniesieniu do konieczności zachowania dystansu społecznego. Niemniej

\footnotetext{
na poziomie od 30 do 50 procent potwierdzity już Francja, Wielka Brytania, Chiny, Australia, Hiszpania czy Nowa Zelandia. - W Polsce instytucje rzadowe nie podjęty tematu. A. Dobkiewicz, W kwarantannie wzrasta przemoc domowa. Czy polskie wtadze to zauważa? https://wroclaw.wyborcza.pl/ wroclaw /7,35771,25859370,w-kwarantannie-wzrasta-przemoc-domowa-czy-polskie-wladzeto.html, [dostęp: 02.05.2020].

22 Badania zostały przeprowadzone na próbie 7100 osób. Rodzice, uczniowie i pracownicy szkoły (nauczyciele oraz pracownicy administracji) wypowiedzieli się na temat funkcjonowania szkoły w trybie zdalnym. Szerzej na ten temat w: S.G. Huber i in., COVID-19 - aktuelle Herausforderungen in Schule und Bildung Erste Befunde des Schul-Barometers In Deutschland, Österreich und der Schweiz, WAXMANN, Schul-Barometer, https://www.waxmann.com/index.php? eID=download\&buchnr=4216, [dostęp: 15.05.2020].
} 
jednak, zgodnie ze wskazaniami uczniów, 40\% nauczycieli nie wykorzystuje możliwości technologicznych, prowadząc lekcje online w czasie rzeczywistym ${ }^{23}$. Utrzymujący się stan zamknięcia szkół przekłada się również na wysoki poziom stresu uczestników procesu dydaktycznego, co niewątpliwie jest elementem wspólnym dla każdej społeczności szkolnej, niezależnie od jej geograficznego położenia.

\section{Podsumowanie}

Uwzględniając zaistniałą sytuację, szkoły stanęły przed wyborem pomiędzy nauczaniem zdalnym a utratą kilku miesięcy nauki. Wybór edukacji online nie jest pozbawiony wad. Głównym czynnikiem negatywnym zdaje się być to, że znaczna grupa uczniów, znajdująca się w niekorzystnej sytuacji, nie posiadająca narzędzi do pracy oraz wsparcia pozostanie w tyle. Dzieci i młodzież z „uprzywilejowanych środowisk" odnajdą narzędzia, których potrzebują, otrzymają wsparcie, na które ich rodzice będą sobie mogli pozwolić, na przykład w postaci korepetycji online i tym podobnych. Jednakże ta część, która znajdzie się w niekorzystnej sytuacji, stanie przed wieloma wyzwaniami. Pandemia i związane $\mathrm{z}$ nią następstwa w postaci redukcji wielu miejsc pracy, wzrost cen żywności spowodowanych suszą, pozbawią wiele rodzin buforów finansowych zapewniających im spokojny byt. W takiej rzeczywistości kluczem do sukcesu edukacyjnego wydają się nie tylko rozwiązania technologiczne, dostępne dla wszystkich uczniów, zarówno na wypadek kontynuowania kształcenia zdalnego jak i w bezpośrednim kontakcie z uczniem, ale przede wszystkim relacja między uczniami i nauczycielami, nacechowana zaangażowaniem i wymianą emocjonalną ${ }^{24}$, która winna być podstawowym elementem pracy. Należy także podkreślić, iż obecna sytuacja wymaga ukierunkowania pomocy nie tylko na uczniów, ale również nauczycieli.

Technologia jest niewątpliwie szansą dla edukacji w okresie rozprzestrzeniania się pandemii, niemniej jednak niesie ze sobą ryzyko „zachłyśnięcia się" innowacyjną technologią, tracąc z oczu szeroko pojętą jakość nauczania. Implementowaniu nowoczesnych technologii na grunt edukacji musi towarzyszyć przygotowanie wskazówek do ich wykorzystania, stymulujących proces samoregulacji uczenia się ${ }^{25}$. Świadoma regulacja własnych działań w sytuacji

${ }^{23}$ Odsetek nauczycieli prowadzących lekcje cyfrowe: 10\% - żaden, 21\% - mała część, 9\% połowa, 35\% - większość, 22\% - wszyscy. Tamże, s. 56.

${ }^{24}$ H. Sęk. Wypalenie zawodowe u nauczycieli. Uwarunkowania i możliwości zapobiegania, [w:] Wypalenie zawodowe. Przyczyny, mechanizmy, zapobieganie, red. H. Sęk, Warszawa 2000, s. 99.

${ }_{25}$ T. Surma, P.A. Kirschner, Technology enhanced distance learning should not forget how learning happens, Computers in Human Behavior, September 2020, 110. 
przeniesienia całego procesu nauczania na płaszczyznę kontaktów zapośredniczonych jest niezwykle ważna. Regulacja sterowana podejmowana przez nauczycieli z wykorzystaniem nowoczesnych technologii jest wyjątkowo trudna. Brak bezpośredniej interakcji często skutkuje tym, że mimo ogromnego nakładu pracy nauczycieli, uczniowie nie są zainteresowani przyswojeniem wiedzy. Taki stan rzeczy dobitnie ilustruje sytuacja opisana przez jednego z rodziców:

Pewnego poranka, ku mojemu zdziwieniu, z pokoju nastoletniego syna, zamiast zwyczajowych wygłupów znanych youtuberów, doszty mnie dźwięki bardzo sensowego wykładu na temat historii relacji izraelsko-palestyńskich. (...). Wykład, w przeciwieństwie do poranków (żartów) youtuberów, był niezmiernie ciekawy. Okazało się, że mój licealista ma wykład z historii najnowszej prowadzony przez nauczyciela przez aplikacje Zoom. Wszedtem do pokoju - chciatem pochwalić syna, że wreszcie słucha czegoś mądrego. Okazało się, że na laptopie ma wykład historyka ze szkoty, na PlayStation gra w FIFE, a na smartfonie komunikuje się z kumplami. Wszystko w jednym czasie ${ }^{26}$.

Wielozadaniowość definiowana jako wykonywanie kilku zadań jednocześnie, będąca udziałem wielu młodych ludzi, jest ściśle związana z rozprzestrzenianiem się technologii. Badania wskazują negatywny wpływ wielozadaniowości na proces przyswajania wiedzy ${ }^{27}$, dlatego tak istotne jest, w kontekście możliwej realizacji zadań szkoły w trybie zdalnym w przyszłości, zwrócenie szczególnej uwagi na rozwój umiejętności samoregulacji² ${ }^{28}$.

Korzystanie z platformy edukacyjnej ma wyraźne korzyści, ułatwia szybki dostęp do materiałów edukacyjnych skracając czas potrzebny na kopiowanie kart pracy, rozdawanie prac i ich zbieranie, dobrze przygotowane zadanie usprawnia sprawdzanie, a tym samym otrzymanie przez ucznia informacji zwrotnej ułatwiającej mu dalszą pracę. Pandemia całkowicie zakłóciła przebieg edukacji, zakłóciła system koncentrujący się na tradycyjnych umiejętnościach. Niezależnie jednak od różnorakich opinii na temat nauczania zdalnego oczywiste jest, że wynikające z konieczności przejście na naukę online w czasie pandemii może, a nawet powinno być katalizatorem zmian w obszarze edukacji.

${ }^{26}$ S. Łupak, Zdalne nauczanie: plotkary z ostatniej ławki wreszcie mnie nie rozpraszaja, https:// ksiazki.wp.pl/zdalne-nauczanie-elekcje-szkola-online-koronawirus-kwarantanna-edukacja-domowa-nauczanie-w-domu-pandemia-6504384771757697a, [dostęp: 30.04.2020].

27 Szerzej na ten temat w: L. Bowman i in., Can students really multitask? An experimental study of instant messaging while reading, Computers \& Education, 2010, 54(4), s. 927-993.

${ }_{28}$ Badania dowodzą, że „uczniowie płci męskiej na zajęciach online wykazują niższe poczucie skuteczności w zakresie efektywnego regulowania swoich zachowań i przeciwdziałania rozpraszaniu podczas nauki". A. Alghamdi, A.C. Karpinski, J. Barkley, Online and face-to-face classroom multitasking and academic performance: Moderated mediation with self-efficacy for self-regulated learning and gender, Computers in Human Behavior, 2020, 102, s. 220. 


\section{BIBLIOGRAFIA}

Alghamdi A., Karpinski A.C., Barkley J., Online and face-to-face classroom multitasking and academic performance: Moderated mediation with self-efficacy for self-regulated learning and gender, Computers in Human Behavior, 2020, 102.

Beaunoyer E., Dupéré S., Guitton M.J., Covid-19 and digital inequalities: Reciprocal impacts and mitigation strategies, Computers in Human Behavior. 2020, 111.

Bowman L., Levine L.E., Waite B.M., Gendron M., Can students really multitask? An experimental study of instant messaging while reading, Computers \& Education, 2010, 54(4).

Dobkiewicz A., W kwarantannie wzrasta przemoc domowa. Czy polskie władze to zauważa? https:/ / wroclaw.wyborcza.pl/wroclaw /7,35771,25859370,w-kwarantannie-wzrasta -przemoc-domowa-czy-polskie-wladze-to.html, [dostęp: 02.05.2020].

Huber S.G., Günther P.S., Schneider N., Helm C., Schwander M., Schneider J.A., Pruitt J., Covid-19 - aktuelle Herausforderungen in Schule und Bildung Erste Befunde des Schul-Barometers In Deutschland, Österreich und der Schweiz, WAXMANN, Schul-Barometer, https:/ / www.waxmann.com/index.php?eID=download\&buchnr=4216, [dostęp: 15.05.2020].

Hurwitz L.B., Schmitt K.L., Can children benefit from early internet exposure? Short- and longterm links between internet use, digital skill, and academic performance, Computers \& Education, 2020, 146.

Kucuk S., Richardson J.C., A structural equation model of predictors of online learners' engagement and satisfaction, Online Learning, 2019, 23(2).

Łupak S., Zdalne nauczanie: plotkary z ostatniej tawki wreszcie mnie nie rozpraszaja, https:// ksiazki.wp.pl/zdalne-nauczanie-elekcje-szkola-online-koronawirus-kwarantanna-edukacja-domowa-nauczanie-w-domu-pandemia-6504384771757697a, [dostęp: 30.04.2020].

Putz L.M., Hofbauer F., Treiblmaier H., Can gamification help to improve education? Findings from a longitudinal study, Computers in Human Behavior, 2020, 110.

Raes A., Vanneste P., Pieters M., Windey I., Van Den Noortgate W., Depaepe F., Learning and instruction in the hybrid virtual classroom: An investigation of students' engagement and the effect of quizzes, Computers \& Education, 2020, 143.

Sęk H., Wypalenie zawodowe u nauczycieli. Uwarunkowania i możliwości zapobiegania, [w:] Wypalenie zawodowe. Przyczyny, mechanizmy, zapobieganie, red. H. Sęk, Wydawnictwo Naukowe PWN, Warszawa 2000.

Sun J-N., Hsu Y-C., Effect of interactivity on learner perceptions in web-based instruction, Computers in Human Behavior, 2013, 29(1).

Surma T., Kirschner P.A., Technology enhanced distance learning should not forget how learning happens, Computers in Human Behavior, September 2020, 110.

Viner R.M., Russell S.J., Croker H., Packer J., Ward J., Stansfield C., Mytton O., Bonell Ch., Booy R., School closure and management practices during coronavirus outbreaks including Covid-19: a rapid systematic review, Lancet Child Adolesc Health, 2020, 4. 